Crime, Histoire \& Sociétés / Crime, History \& Societies

Vol. 21, $n^{\circ} 2$ | 2017

L'histoire de la criminalité et de la justice pénale : propositions de recherche pour le $21^{\mathrm{e}}$ siècle

\title{
Future Perspectives on Crime Control Under 20th Century Authoritarian Regimes
}

Tiago Pires Marques and Tiago Ribeiro

\section{(2) OpenEdition \\ Journals}

Electronic version

URL: http://journals.openedition.org/chs/1813

DOI: $10.4000 /$ chs. 1813

ISSN: 1663-4837

\section{Publisher}

Librairie Droz

\section{Printed version}

Date of publication: 31 December 2017

Number of pages: 105-111

ISSN: $1422-0857$

\section{Electronic reference}

Tiago Pires Marques and Tiago Ribeiro, "Future Perspectives on Crime Control Under 20th Century Authoritarian Regimes", Crime, Histoire \& Sociétés / Crime, History \& Societies [Online], Vol. 21, n² | 2017 Online since 19 July 2020, connection on 12 January 2021. URL: http://journals.openedition.org/chs/ 1813 ; DOI: https://doi.org/10.4000/chs.1813 


\title{
Future Perspectives on Crime Control Under 20th Century Authoritarian Regimes
}

\author{
Tiago Pires Marques, Tiago Ribeiro
}

Historical studies of the institutions and practices of criminal repression in twentieth-century authoritarian regimes are invariably confronted with two interrelated problems. The first concerns the demarcation of the thus defined socio-political universes. Here let us limit ourselves to noting that, after World War I, a number of societies shared comparable features in state and juridicalpenal organization. These societies were historically distinguished by a rhetoric that involved motives for a rupture with a previous (liberal) order and the construction of a "new order". Whether we speak of Italian Fascism (1922-1945), of the Portuguese Estado Novo (1933-1974), the Spanish Francoist regime (1939-1977), the Romanian National Legionary State (1940-1941), and the Vargas Estado Novo period in Brazil (1937-1945), among others ${ }^{1}$, we are faced with concepts that were intended to establish a new state-based order and a new relationship between the state and the individual. The second problem involves a common historiographical dilemma. If, on the one hand, history has the task of understanding the logics of historical actors and whom or what they represented; on the other hand, it imposes upon itself the mission of understanding/explaining the past in terms of the practical rationales and of their duration in time that only a distanced perspective can construct. This distance implies the dissociation between the discourses of actors and institutions - at least, on a prima facie level - and the analytic discourse of the historian. As an understanding/explanation of the past ${ }^{2}$, history is thus constructed in a dynamic process of reciprocity between the etical categories of the researcher (in this case, historiographical questions) and the emic categories of historical actors (their concepts, representations, justifications, and self images) ${ }^{3}$.

The analysis of the legal-criminal and police regimes of these "new order" states requires an increased vigilance at the epistemic distinction and interplay between etical and emic categories. This requirement is linked, in particular, to the strong rhetorical investment in the topic of political rupture. Yet, and here perhaps less obviously, it results from the equally powerful legal rhetoric of continuity. Looking at the studies published in this field, which are generally vigilant concerning the rhetoric of rupture ${ }^{4}$, new research should strive to intertwine more strongly such historical critique with a critique of the rhetoric of legal and institutional continuity. We can illustrate this methodological need with a concrete example. It is well known that

\footnotetext{
1 We can include here, of course, a number of dictatorships, many led by the military, seen throughout the twentieth century across almost all continents.

2 Ricoeur (2000, p.231-238).

Ginzburg (2013).

$4 \quad$ Hametz (2012), Garfinkel (2016).
} 
in the interwar period, the reform of the nineteenth-century penal codes mobilized hundreds of experts in international networks and congresses. The strengthening of the logic of prevention, mostly through the doctrine of "social defence", topped the priority list of these reformers, in particular by codifying security measures and legal categories such as the "habitual criminal" and the "criminal by tendency". Yet in these arenas designed to offer recommendations to legislators, the prevailing rhetoric amounted to the continuation of the previous criminal law and practices. It is undoubtedly right that many historians call attention to the fact that these categories were indeed grounded in concepts and practices observed in the nineteenth century. However, there is a tendency to disregard their thoroughgoing inclusion - as opposed to their administrative or exceptional character - into legal codes and their impact on the fabric of new institutions (e.g. surveillance judges, penitentiary law and newly codified systems of police sanctions $)^{5}$.

This neglect is explicable, of course, by the sound historiographical attitude of emphasising practices over concepts. However, it obscures the observable strategies legal actors deploy in order to innovate, and chief among these that of consensusmaking on the definition of legal order and tradition. Let us clarify this point with a brief historical illustration. With the approach of World War II, international penal networks - such as the International Penal and Penitentiary Commission, the International Union of Criminal Law, and the Conferences for the Unification of Penal Law - gradually reflected the rising tensions between European nations. However, just a few months before the Nazi invasion of Poland, Vespasian Pella, an eminent Romanian criminologist, still entertained the hope that the common fight against crime would contribute to restoring the political dialogue 6 . In his words, the "stability of the law" even compensated for the unexpected evolution of certain penal systems, while a few other elements united the now politically clashing states in a single cause: the commitment to the scientific serenity of being neither too progressive nor too old-fashioned (an aspiration which took the form of scientific eclecticism), the fight against international crime and the protection of "state identity".

This criminologist's reflections are representative of a class of professionals for whom innovations were to be legitimized by a high degree of consensus on their capacity for developing, rather than breaking, constitutional and legal traditions. As other authors have argued, the first concern in any research agenda on these topics may then well be careful periodization on the historical perceptions of the continuities and ruptures with the pre-existing juridical and institutional configurations ${ }^{7}$. As these experts by no means constituted a homogeneous group, these perceptions are also to be analyzed in accordance with the actors' education and training and role in the judicial, prison and police systems. Additionally, this exercise allows us to observe the limits beyond which significant segments of jurists and criminologists understood that the institutional order was at risk or had already been breached. In this regard, it is worthwhile pointing out that issues such as criminal eugenics (specially in Latin countries), the enforcing of the Racial Laws in fascist Italy in 1938, and the proliferation of special tribunals for the defense of the State, were far from gathering support from all leading experts in the field, even among those

Marques (2016, p.109-133).

Pella (1939).

Fraser (2015, p.201); Skinner (2015a, p.61). 
supporting the authoritarian regimes in their countries ${ }^{8}$. International networks and congresses, especially since the mid-1930s, actually constituted a privileged arena in which reformers expressed their dissent. While we already know much about the ways in which these expert forums acted as producers of consensus, the significance of such arenas in the elaboration of limits to the expansion of the repressive and preventive measures by authoritarian states remains an open field of research.

This question is all the more significant as we can observe, in the late 1930s, the emergence of discourses arguing that regimes such as Nazi Germany and the USSR - but to a much lesser extent Mussolini's Italy - had clearly left the "civilized world" of the rule of law. From this perspective, the study of penal reforms may prove useful in further elucidating the historical role of the interplay of the "disturbing lawfulness of fascism" with the expansion of strongly repressive rationales and racist discourses in ensuring both the conquest of the state and the diminishing capacity of political dissidence and resistance. By the same token, a renewed perspective on penal reforms along some of these lines may also prove helpful in grounding abstract discussions on the "nature" of fascisms and the continuities/discontinuities with regard to democratic regimes, in concrete historical configurations. With this agenda in view, new research questions acquire greater urgency: how did interwar juridical-penal and police reforms affect the concept of legality? How did discourses on such reforms and enforced institutional changes affect the ways in which judges, lawyers, law professors, prison directors, police officers and other gatekeepers of order conceived and practiced their professions? And how did the blurring of the "criminal" and "the enemy of the state" redefine the boundaries between the private and public ${ }^{10}$ ?

These questions cry out for the combination of discourse analysis with a closer observation of practices. For instance, we know relatively little about the ways in which authorities enforced security measures and how they combined them with legal sentences. The same applies to the channels between special tribunals and ordinary juridical-penal systems. From the same double perspective on political/expert discourses and institutional practices, it is also urgent to undertake a new mapping out of the styles and zones of criminal and social control, extending from the core of the state apparatuses (namely, prisons) to territories of exile (penal colonies). This charting of control must, of course, extend to the colonies of European powers, a domain still largely unexplored.

Again, from this double perspective, the now exhausted debate on the penal continuities and discontinuities between fascism and democracy is to be recast into a much more vigorously critical approach on the concept of legacy.

\section{LEGACIES}

Historical legacy is a subject that has been involved in multiple debates, namely around the penal governance of contemporary societies, exhibiting a myriad of empirical and theoretical nuances. One of its peculiarities relies on the intellectual appeal of the reconstitution of cultural, normative and institutional codes and nexuses

Marques (2016, p.161-166).

Skinner (2015b, p.7).

10 Fraser (2015, p.199). 
that feed the aspiration to understand the influence of the past in the way present time is experienced and configured. As a research project, this approach to the socio-legal field requires different clarifications about legacy as an umbrella that is, for different reasons, widespread in the public sphere and that justifies an autonomous analytical program. Recognizing the influence of the current reading frameworks on memory dispositions and narrative elaboration of the past (that is, on the historiographical production) is a commonplace in the circles of humanities scholars and the scientific community. So the analysis of the historical legacy - whose core aim is offering visibility and intelligibility to the effects of the past to the modern observer - is far from dispensing a critical judgment on the epistemological presuppositions of the questions asked and the answers obtained. As a legacy gauge, the idea of transmission is itself a source of paradoxes ${ }^{11}$ whose modes of resolution usually depend on the standpoint and/or the agenda in which their enunciation lies.

These standpoints and/or agendas work both as a matrix of interpretation and devices of visibility/concealment in the wider challenge of thinking about historical legacy in criminal governance. They often arise from a constellation of different backgrounds and bodies of knowledge (history, law, political science, and other social sciences) and specific research contexts or interests, such as claiming a historical inheritance or denouncing a historical trauma within a given moral economy. They define the modes of imagination and the reasons of invocation of the past ${ }^{12}$, in order to establish an inspiring and productive relationship with the modes of description and representation of the present and its possible trends. The umbilical nature of this relationship is especially conveyed by the historical legacy heuristics. It then requires critical awareness not only of the unavoidable risks of a (dis)continuity illusion (cf., mutatis mutandis, the concept of "biographical illusion" from Pierre Bourdieu ${ }^{13}$ ), but also of the pervasive power of legal categories, historiographical sequentialism, and politico-logical schemes in modulating the task of essaying criminal governance across time. As a matter of fact, although the transition from authoritarian to democratic regimes has become a self-evident criterion of legal change (for law is both source and outcome of change), it does not mean that the socio-criminal grammar that supports the governmentality managed within democratic regimes has no regard for state repertoires of knowledge and state technologies of power which authoritarian legality developed and institutionalized ${ }^{14}$. At the same time, the engagement in new political and epistemological concerns on crime and control, truth and subjectification ${ }^{15}$, demands scholarly reflection on the asking of new questions and the search for new meanings on the (apparently) very same reality that has been studied over the last decades.

One of the most common, although promising, clues that can guide the exercise of contrasting binomial concepts such as past and present, authoritarianism and democracy, normality and exception, coercion and hegemony, is the principle of security ${ }^{16}$ and

\footnotetext{
11 Ost (1999).

12 Traverso (2012).

13 Bourdieu (1986).

14 Marques (2016, p.5-10).

15 Foucault (2014).

16 Foucault (2009).
} 
the idea of dangerousness ${ }^{17}$ as sources of legitimacy, legibility and operability. The encroachment of social defence in common sense encountered repressive and ideological special conditions of possibility ${ }^{18}$ with the emergence of authoritarian regimes, despite its meta-influence both in reactionary and progressive movements and agendas. The investment and modernization of the police apparatus, the expansion and sophistication of criminology and forensic expertise ${ }^{19}$, the executive concentration of power, the promotion of a consentaneous criminal jurisprudence, the political management of (de)judicialization solutions and the collective mobilization for an ideal of social sanitization and prosperity; all played a dynamic role in the profiling of a dangerous subject conceived as potential enemy of the state (political enemy) or community (social enemy) ${ }^{20}$. The consolidation of a pre-emptive rationale simultaneously supports and comes from the (not so straightforward) coalition between law, intelligence, and psychiatry, a complex and useful source of order and truth that enabled the governance of the threat to state/society and the implementation of appropriate security and rehabilitation measures.

Contemporary meanings and uses of social defence rationales cannot be understood without a critical review of the political, legal (criminal, constitutional) and scientific disputes and transformations in which they are now grounded. On the one hand, this new societal scenario puts the authoritarian genesis or disposition of social defence principles in perspective, making its modes of production of truth and morality more opaque, ambivalent and less self-sufficient. On the other hand, this very same new societal scenario highlights that authoritarian genesis or disposition, requiring a theoretical effort to identify the new enemies, the apparatus of power, the technologies of the self, and the cultural beliefs that now support the democratic government when it perceives dangerousness. That is why criminal governance solutions, trends or contingencies are a field of inquiry which when addressed critically cannot neglect the historical genealogy of many of the discourses, concerns, and temptations that are now surrounding common sense topoi and legal reform agendas.

While in the fascist years, the personifications of racial types, political dissidents, and homosexuals, among others, loomed largest as the "enemies of the nation and the state", today "terrorists" and "sex offenders" represent powerful socio-legal categories around which, for different reasons, moral panic has been cultivated ${ }^{21}$. In public debate, they are probably the phenomena most likely to trigger a symbolic memory of an authoritarian imperative. The emergence of a pseudo-ethics of plea bargaining creates the conditions to mobilize terrorist and sex offender subjects as categories that share a congeneric profile of danger. Both categories result in a community panic which is functional in the invocation of a categorisation of exception ${ }^{22}$ and the establishment of what Günter Jakobs ${ }^{23}$ called an "enemy criminal law". In fact, the legal establishment and police struggle against cybercrime related to sexual and

\footnotetext{
Foucault (2014).

18 Hunt and Wickham (1994).

19 Pasquino (1991).

20 Marques (2016, p.120-129).

21 Boukalas (2008), Lancaster (2011).

22 Agamben (2009).

23 Jakobs (2014).
} 
political terror has become a research object with an enormous epistemological potential, as it enables the access to legal, moral and truth regimes. Aspiring to a "cognitive security" ${ }^{24}$, intellectual blackmailing, precautionary logics ${ }^{25}$, expertization of governance ${ }^{26}$ and community involvement ${ }^{27}$ are condensed into a citizenship of war and a "neurotic state" 28 which criminalizes fantasy and, of course, fantasizes criminality. This is a foggy and complex process that may put both in perspective and in evidence the legacy of authoritarian orders in contemporary systems of crime prevention and control. On the one hand, it enables researchers to understand, for instance, to what measure the expansion of the forensic field and the emergence of new epistemic repertoires, such as the neurosciences, reproduce old psycho-political models. On the other hand, it helps to deal with the idea that controlling the meaning of the past gives legal players resources and advantages in organising a collective belief about the present.

These specific topics are only examples of different resonances of authoritarian defence approaches, the historiographical research of which can help to confront contemporary analytical challenges. In addition, their contemporary forms prove to be instrumental in the drafting of new historiographical clues. Concurrently, the general frame of Foucauldian inspiration has been leading a significant part of the critical research around the history of criminal governance, enriched by the population shift empowered by biopolitical studies and by the rediscovery of pastoral and disciplinary logics inscribed in unsuspected dimensions of social life under authoritarian regimes (as well as under societies of control). Its analytical virtue should not lead to an epistemological automatism or inertia that converts its potentialities into an impoverishment factor for the task of historiographical questioning.

This means that a global picture of the state's normalizing power-knowledge tools should enter a dialogue with other intellectual hypotheses enabling the investigator to confront objects, contradictions, ambiguities or nuances that belong to the authoritarian (sub)legal field and imaginary, but which could not entirely fit in that grid or which could give rise to other types of research concerns. This obviously requires an ethnography in the archives ${ }^{29}$ and an ambitious incursion into the universe of legal forms ${ }^{30}$, crossing documental with oral sources ${ }^{31}$. According to the strategic research object selected and the intellectual debates it may help to deepen or supersede, different dimensions of criminal governance are far from being exhausted: namely the manufacturing of legal reasoning around the reasonable man abstraction, the explicit or tacit profiling of victims and offenders, the criminal framing of guilty, innocent or unnamable subjects, care protocols developed or applied security devices ${ }^{32}$. It is also possible to find new interesting data and research on innovative approaches within legal (and connected) profession discourses, identities,

\footnotetext{
24 Jakobs (2014, p.420).

25 Salas (1999).

26 Boukalas (2012a).

27 Boukalas (2012b), Lowenkron (2013).

28 Boukalas (2012b, p.132).

29 Merry (2002).

30 Foucault (2000).

31 Portelli (1997).

32 Agamben (2005).
} 
socialization and regulation, state and self-describing legal categories, active means of establishing proof (avowing, witnessing, calling on experts), litigation strategies and performances, anecdotal contents and cases, unwritten normativity and systemic contingencies emerged from micro or interactional scales ${ }^{33}$.

Challenging and rethinking the self-evident taxonomy of the legal and forensic field $^{34}$ is a task that may benefit from a careful scrutiny of the migration of words and ideas, whose evidence can only be obtained through the inclusion of a wider and diverse body of empirical data in socio-legal research ${ }^{35}$, so that the sense of law can be rescued from its scientific-administrative standard ${ }^{36}$. If the well-known presence of criminal and forensic concepts and patterns in the literary world has been studied in different contexts ${ }^{37}$, the reverse could give back stimulating results for the comprehension of the symbolic resources for legal judgment.

Criminal governance cannot be critically understood without taking into account the different evidence of social antagonism it receives and produces. The dynamics of contentious politics ${ }^{38}$ and its interfaces with legal arenas ${ }^{39}$ marked an entire program of research grounded in the political sociology of law that dealt with the structure of legal opportunities that liberal institutions offered to collective action. However, the weight of this approach to the legal field, conceived as a competitive territory for political battles, does not exhaust the historical potentiality of the study of political opposition or resistance to repressive legality and criminal apparatus itself. As the delinquent subject did not give linear place to a political player, the preference for a scaling up of the subpolitics ${ }^{40}$ of criminal resistance may help to reveal dimensions of the authoritarian contexts that have hitherto remained outside the study of criminal governance and that may prove useful to the understanding of the contemporary tensions that characterize criminal experience.

\author{
Tiago Pires Marques \\ Centre for Social Studies \\ University of Coimbra \\ tmarques@ces.uc.pt \\ Tiago Ribeiro \\ Centre for Social Studies, \\ University of Coimbra \\ tiagor@ces.uc.pt
}

\footnotetext{
33 Ginzburg (1999), Goffman (1990).

34 Stolen (2002).

35 Ewick and Silbey (1998).

36 Israël (2008).

37 Brooks (2001).

38 McAdam et al. (2001).

39 Hunt (1990).

40 Beck (1997), Scott (1990).
} 


\section{Acknowledgments}

Tiago Pires Marques acknowledges the financial support of the exploratory project "The Fabric of Mental Health. Medical Power, Secularity, and the Psychotherapeutic Field in Portugal (1940s-1990s)", funded by the Portuguese Foundation for Science and Technology (FCT) IF/01589/2013/CP1164/CT0005.

Tiago Ribeiro acknowledges the financial support of his Ph.D. project in Sociology, funded by the Portuguese Foundation for Science and Technology (FCT) SFRH/BD/105231/2014.

\section{BIBLIOGRAPHY}

Agamben, G. (2005) State of exception, Chicago and London: University of Chicago Press.

Agamben, G. (2009) “What is an apparatus?” and other essays, Standford, Stanford University Press.

Beck, U. (1997) Subpolitics: ecology and the disintegration of institutional power, Organization \& Environment, 10, 1, p.52-65.

Boukalas, C. (2008) Counterterrorism legislation and the US state form: authoritarian statism, phase III, Radical Philosophy, 151, p.31-41.

Boukalas, C. (2012a) Government by experts: counterterrorism intelligence and democratic retreat, Critical studies on terrorism, 5, 2, p.227-296.

Boukalas, C. (2012b) US Citizen Corps: pastoral citizenship and authoritarian statism, Situations: a project of the radical imagination, 4, 2, p.117-140.

Bourdieu, P. (1986) L'illusion biografique [The biographical illusion], Actes de la recherche en sciences sociales, 62/63, p.69-72.

Brooks, P. (2001) Troubling confessions: speaking guilt in law and literature, Chicago and London: University of Chicago Press.

Ewick, P. and Silbey, S. (1998) The common place of law: stories from everyday life, Chicago, The University of Chicago Press.

Foucault, M. (2000) Truth and juridical forms', in Faubion, J. (Ed.), Power, New York, New Press.

Foucault, M. (2009) Sécurité, territoire, population [Security, territory, population], Paris: Gallimard.

Foucault, M. (2014) Wrong-doing, truth-telling: the function of avowal in justice, Chicago: University of Chicago Press.

Fraser, D. (2015) Afterword. Through the Looking Glass: Thinking About and Working Through Fascist Criminal Law, in Skinner, S. (Ed.), Fascism and Criminal Law. History, Theory, Continuity. Oxford and Portland: Hart Publishing, p. 197-208.

Garfinkel, P. (2016) Criminal Law in Liberal and Fascist Italy, Cambridge: Cambridge University Press.

Ginzburg, C. (1992) The cheese and the worms: the cosmos of a sixteenth-century miller, Baltimore, Johns Hopkins University Press.

Ginzburg, C. (2013) Our Words, and Theirs: A Reflection on the Historian's Craft, Today, Chromohs, 18, p. 97-114.

Goffman, E. (1990) Stigma, London: Penguin, 1990. 
Hametz, M. (2012) In the Name of Italy: Nation, Family, and Patriotism in a Fascist Court, New York: Fordham University Press.

Hunt, A. (1990) Rights and social movements: counter-hegemonic strategies, Journal of law and society, 17, p.309-328.

Hunt, A. and Wickham, G. (1994) Foucault and law: towards a sociology of law as governance, London: Pluto Press.

Israël, L. (2008) Question(s) de méthodes : se saisir du droit en sociologue, Droit et société, 69-70, p.381-395.

Jakobs, G. (2014) On the theory of enemy criminal law, in Dubber, M. D. (Ed.), Foundational texts in modern criminal law, Oxford: Oxford University Press, p.415-424.

Lancaster, R.N. (2011) Panic: a guide to the uses of fear, in Sex, panic and the punitive state, Berkeley, University of California Press, p.23-38.

Lowenkron, L. (2013) A cruzada antipedofilia e a criminalização das fantasias sexuais [The anti-pedophile crusade and the criminalization of sexual fantasies], Sexualidad, salud y sociedad, 15 , p.37-61.

Marques, T.P. (2016), Crime and Fascist State, 1850-1940, London and New York, Routledge.

McAdam, D.; Tarrow, S. and Tilly, C. (2001) Dynamics of Contention, Cambridge, Cambridge University Press.

Merry, S.E. (2002) Ethnography in the archives, in Starr, J. and Goodale, M. (Eds.), Practicing ethnography in law: new dialogues, enduring methods, New York: Palgrave Macmillan, p.128-142.

Ost, F. (1999) Le temps du droit, Paris: Odile Jacob, 1999.

Pasquino, P. (1991) Criminology: the birth of a special knowledge, in Burchell, G.; Gordon, C. and Miller, P. (Eds.), The Foucault effect: studies in governmentality, Chicago: University of Chicago Press, p.105-118.

Pella, V. (1939) Conférence Internationale d'Unification du Droit Pénal. Sous le Haut Patronage de S. M. Farouk 1 ${ }^{\text {er }}$, roi d'Egypte (Le Caire 12-18 janvier 1939). Actes de la Conférence publiés sous la direction de Abdel Hamid Badaoui Pacha, S.E., Paris.

Portelli, A. (1997) The Battle of Valle Giulia. Oral History and the Art of Dialogue, Madison: The University of Wisconsin Press.

Ricoeur, P. (2000) La mémoire, l'histoire, l'oubli, Paris, Éditions du Seuil.

Salas, D. (1999), O delinquente sexual [The sex offender], in Garapon, A. and Salas, D. (Eds.), A justiça e o mal [Justice and evil], Lisbon: Instituto Piaget, p.45-74.

Scott, J. (1990) Domination and the art of resistance: hidden transcripts, New Haven and London: Yale University Press.

Skinner, S. (2015a) Introduction. Fascism and Criminal Law, One of the Greatest Attributes of Sovereignty, in Skinner, S. (Ed.), Fascism and Criminal Law. History, Theory, Continuity. Oxford and Portland: Hart Publishing, p.1-11.

Skinner, S. (2015b) Fascist by Name, Fascist by Nature? The 1930 Italian Penal Code in Academic Commentary, 1928-46, in Skinner, S. (Ed.), Fascism and Criminal Law. History, Theory, Continuity. Oxford and Portland: Hart Publishing, p.59-84.

Stolen, A.L. (2002) Colonial archives and the arts of governance, Archival science, 2, p.87-109.

Traverso, E. (2012) O passado, modos de usar: história, memória e política [The past, ways of using: history, memory, and politics], Lisbon: Unipop. 